Volume 10, No.4, July - August 2021

International Journal of Advanced Trends in Computer Science and Engineering

Available Online at http://www.warse.org/IJATCSE/static/pdf/file/ijatcse111042021.pdf

https://doi.org/10.30534/ijatcse/2021/111042021

\title{
Does the Education Games with adding some Entertainment Game Elements will attract the children?
}

\author{
Wirawan Istiono ${ }^{1}$ \\ ${ }^{1}$ Universitas Multimedia Nusantara, Indonesia, wirawan.istiono@umn.ac.id
}

\begin{abstract}
This research is a continuation of previous research to find out why early childhood children are not too interested to playing educational games than entertainment games, even though both are games, why the children more prefer to play entertainment games? Even though, if the children love to play educational games, there are many benefits they will get, such as new knowledge, productivity and many other benefits. This research aims to determine the level of user acceptance of educational games that build with adding some common elements of entertainment games. This research methodology begins with questions and answers, surveys and interviews to parents who have early childhood aged 5 to 8 years, with the aim of obtaining information, what are entertainment games are favored by children, then, in this research step, the research will continue with the analysis, design and creating education game that applies elements of entertainment games, such as character elements, animation, praise sound and also an attractive colorful user interface to determine the level of user acceptance of the education game application that was built with the addition of entertainment game elements. After creating an education game application with the addition of game entertainment elements, and after testing user acceptance, it was found that the education game with the addition of several entertainment game elements has not been able to attract early childhood to continue playing education games, this is shown from the average result of the questionnaire is only $57.6 \%$, which indicates that there is a need for a significant increase from the education games that have been made.
\end{abstract}

Key words : Education game, Entertainment game, Game elements, Game for children, Mobile games.

\section{INTRODUCTION}

Smartphone technology is common technology in modern society, including early childhood who are accustomed to using smartphones to play or learn. Early childhood is a child aged 0 to 6 years [1]. Early childhood during the Covid-19 pandemic, often used smartphones to attend online virtual classes, but even though smartphones are often used for education, there are still many negative views of smartphone use in children [2], [3], because children still tend to use smartphones to play games and not use smartphone for study [4], [5]. But are the games played or favored by children is educational game? From the research that has been done before, it was found that educational games are not too popular in children [6], because of many things in educational games for children that do not have characters or mascots, and educational games also have boring gameplay, such as there is no reward for every task or questions that were successfully solved by the child, that problem causing the child who played the educational game feel that game was not interesting [7][8].

According to Massachussets Insitute of Technology (MIT), there are several advantages of educational games compared to conventional learning methods, one of the advantages of educational games is the visualization of real problems [9], [10]. And from this research also found other advantages of educational games, such as, an educational games are also very useful for improving children's logic, children creativity and understanding problem, so based on that result research, it can be concluded that educational games can support the educational process[11], [12]. One of the advantages of educational games compared to conventional learning is that there are animations in educational games that can improve memory so that children can store subject matter for a longer time compared to conventional learning [13][14]. Also based on Gouveia research, using educational games as a learning media can improve children's learning productivity, because children can more easly understanding of learning material from different teaching methods [15]-[17]. Based on the previous theory and explanation, this research more focuses to implement entertainment game elements to education game, and to get information user children interest with this method.

Based on the explanation of the problems and theories, in this study, will be made an educational game specifically for early childhood, where the educational games that will have some elements from entertainment games. The following are some of the elements that will be added to the educational game that will be built, first element is mascot elements with cute character that are liked by mostly of children [18], [19], then 
will be added animations for characters or animation for objects [20], [21], and also will be added sounds of praise [22]-[24] when a child answers a question correctly to give positive message to children, and also of course the user interface design and objects will have colorful colors that are suitable for children [25], [26], and hoped, game applications with the addition of these elements can attract children's interest for choosing educational games rather than entertainment games.

This study aims to determine the level of user acceptance of educational games that build with adding some common elements of entertainment games. While the contents for this educational games for early childhood will contain about objects names, starting from knowing the names of objects, guessing the names of objects and how to spelling out the objects names. Of course, all the content that will be created will added with character elements, animation, praise sound and also an attractive colorful user interface. It is hoped that the educational game can be used as an alternative learning media for early childhood, where from conventional learning methods to learning methods using game simulations. The limitation of the problem in this research is, the development of education games in this research is design specific for children with aged between five to eight years old or preschoolers and elementary school children.

\section{METHODOLOGY}

The research step began with observations and surveys that had been carried out at the previous research stage and also carried out literature studies to get field facts about how long early childhood used smartphones. Surveys, observations and interviews were conducted to parents or guardians who have children of preschool and elementary school with age range of children are five to eight years, this first step which were conducted online by asking several questions related to games loved to play by their children, with a total of respondents is 53 , from various student's parents who study in various places in the Tangerang area, Indonesia. From the results of observations, surveys and studies, a surprising fact was found, that the length of time early childhood using smartphones can range from 4 to 6 hours a day. where only 1 to 2 hours are used for learning or online studying, and the rest is used to play the child's favorite game, where on average the games played by these children are not education games, but entertainment games [7], the list of question that asked to student's parent and the answer is shown in Table 1. This beginning step is to get informaton how many children are loved to played digital games, and how long they playing digital games, and what is popular title games in children, and what device they use to playing video games. All information that collected will be useful for analysis what and why that entertainment game that choose by children so popular, and what elements that can be taken and applied in education games.
Table 1: List of question and answer in previous research

\begin{tabular}{|c|c|}
\hline Question & Answer \\
\hline $\begin{array}{c}\text { Does your child like playing } \\
\text { digital games? }\end{array}$ & $\begin{array}{l}\text { Yes: } 51(96 \%) \\
\text { No: } 2(88 \%) \\
\end{array}$ \\
\hline $\begin{array}{l}\text { Has your child ever played } \\
\text { educational-type digital } \\
\text { games? (if the answer is } \\
\text { "yes" in first question) }\end{array}$ & $\begin{array}{l}\text { Yes: } 45(88 \%) \\
\text { No: } 6(12 \%)\end{array}$ \\
\hline $\begin{array}{c}\text { How often does your child } \\
\text { play these educational } \\
\text { games? }\end{array}$ & $\begin{array}{c}\text { Often: } 2(4 \%) \\
\text { Not often: } 49(96 \%)\end{array}$ \\
\hline $\begin{array}{c}\text { Does your child still play } \\
\text { this educational game until } \\
\text { now? }\end{array}$ & $\begin{array}{l}\text { Yes: } 1(2 \%) \\
\text { No: } 50(98 \%)\end{array}$ \\
\hline $\begin{array}{l}\text { What is the title of the } \\
\text { educational game played by } \\
\text { the child? }\end{array}$ & $\begin{array}{c}\text { BabyBus: } 8(16 \%) \\
\text { Educa Games: } 6(12 \%) \\
\text { Other: } 37(73 \%) \\
\end{array}$ \\
\hline $\begin{array}{l}\text { What is the reason for your } \\
\text { child not continuing to play } \\
\text { educational games } \\
\text { anymore? }\end{array}$ & $\begin{array}{l}\text { Don't know: } 47(92 \%) \\
\text { Other reason: } 4(8 \%)\end{array}$ \\
\hline $\begin{array}{l}\text { What are the titles of } \\
\text { entertainment games that } \\
\text { your child usually plays? }\end{array}$ & $\begin{array}{c}\text { Mobile legend: } 16(31 \%) \\
\text { Roblox: } 14(27 \%) \\
\text { Minecraft: } 9(8 \%) \\
\text { Other: } 12(24 \%) \\
\end{array}$ \\
\hline $\begin{array}{c}\text { What game platform does } \\
\text { your child use when playing } \\
\text { digital games? }\end{array}$ & $\begin{array}{c}\text { Smartphone: } 42(82 \%) \\
\text { Console: } 3(6 \%) \\
\text { Game Gadget: } 1(2 \%) \\
\text { PC: } 5(10 \%)\end{array}$ \\
\hline $\begin{array}{l}\text { How long does your child } \\
\text { play games in one day? }\end{array}$ & $\begin{array}{c}\text { Less than } 1 \text { hours/day: } 2(4 \%) \\
\text { 1-2 hours/day: } 12(24 \%) \\
\text { 2-3 hours/day: } 34(67 \%) \\
\text { More than } 3 \text { hours/day: } 3 \\
(6 \%)\end{array}$ \\
\hline
\end{tabular}

After observations and interviewing the parents of student that have been obtained from previous research [7], then in the this research, an education game application will be try to be designed and built with adding some entertainment game elements that are loved by the children, such as character elements, animation, sound of praise, design and user interfaces. Besides that, the education game application is also given voices to guide and make the learning easier to learn for early childhood who don't know the letters yet, so they can understand too the content of the lessons in this education game. Sounds in this education game application are also made in two languages, namely in English and Indonesian. After making an education game application with the addition of game entertainment elements, the child will be tested or asked about this educational game, of course when question and answer session, the children will be assisted by they parents to answer the survey, to get the level of early childhood acceptance toward education games that have added game entertainment elements. The testing will be carried out using a user acceptance test (UAT). 
In the first view of this education game application, will be shown colorful menu to attract children's interests, on the main menu of the education game, besides the title and navigation button for playing the game, there are also a character in the form of a cat with cute animation. The addition of cute character and movable characters or animation is an additional element that commonly found in entertainment games. Beside that the cat that as a main character is given a name, the name of the cat is Sammy. With given name for the character, it is hoped, early childhood will be more interested in the education game application. Also all text and voices on the education game's main menu are also made in two languages, namely Indonesian and English. The main menu of the education game can be seen in Figure 1.

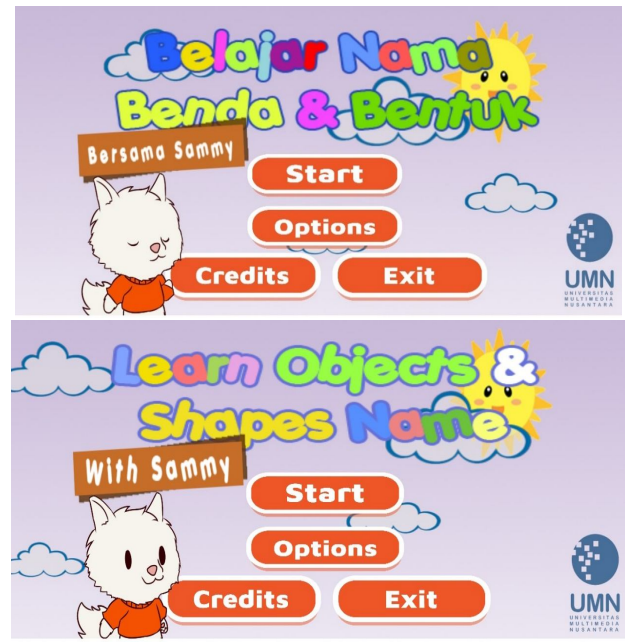

Figure 1: Main menu education game with UI, character and animation

From the main menu that appears in Figure. 1, there are several buttons, one of which is the options button which functions to display the options menu, where the options menu is useful for controlling music and sound effects, to turn on or turn of music or sound, and there is also an option to change the language, where the languages provided by this game are Indonesian and English, where when the language is changed, that will be changes to the text and sound that appears in games. The menu options display can be seen in Figure 2.

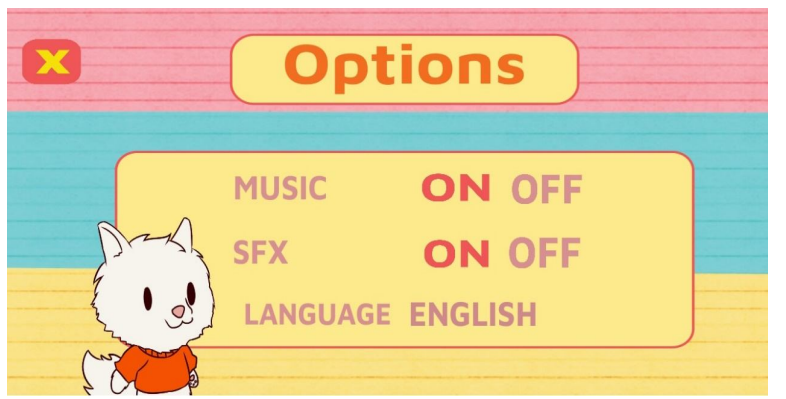

Figure 2: Options menu to control music, sound and change the language
When the Start button of the gameplay is pressed, the game will change the scene to select level menus, as shown in Figure 3, where in the select level menu provides three game options gameplay that can be choose by user, the first gameplay is "Learn the names of objects", the second is "Guess Objects Name" and the third gameplay is "Composing Letters". The gameplay content is design for user can understand the material, first gameplay is design for user can learn or identify name of objects by voices and picture, and the second gameplay, for test user's memory of objects name and the last gameplay is design for user can type the name of objects.

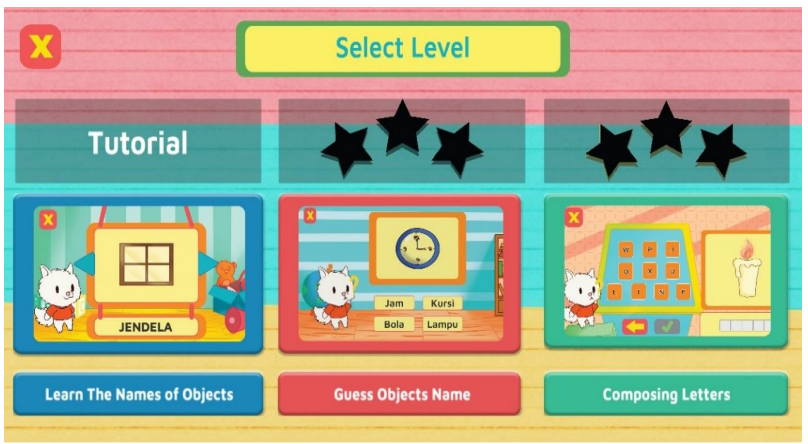

Figure. 3: Select level menu to choose type of games

The first menu is a tutorial game to knowing objects name, the gameplay content will contain about knowing names of objects based on text and voices, so that children can know and recognize the names of objects in this game. In this tutorial game, there are no scoring, because this first gameplay is only targeted children can recognize, know and memorize the names of objects. The first gameplay is shown in Figure 4.

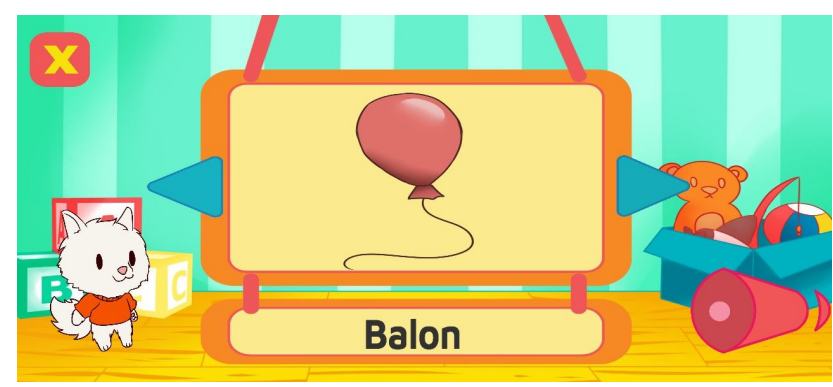

Figure 4: First gameplay, learn the name of objects

The second menu of this game, is the "Guess Object Name", that shown in Figure 5. In this gameplay, the questions will be displayed in the form of images of objects and also the user will be given four answer choices, where the user can choose the right answer option according to the images question, when user choose the correct answer, there will be a sound that says the name of the object, and there will also be happy animations from sammy the cat, and there will also be a cheerful cheering sound, all of these elements aiming to 
motivate the child with praises. But if it's wrong, there will be a sad animation from Sammy the cat, and the child will be asked to answer again, until the answer is correct.

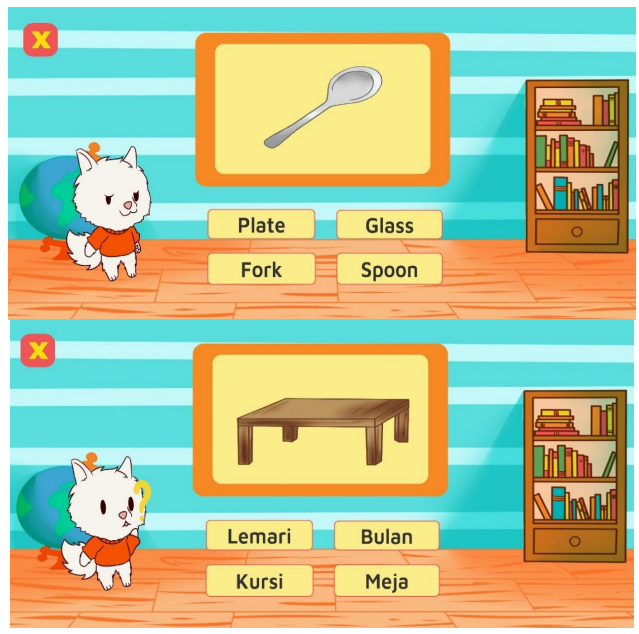

Figure 5: The second gameplay, Guess Object Name gameplay

The last gameplay is the game "Composing Letters" that shown in Figure 6, this gameplay aims to make children not only know and memorize the names of objects, but children are also trained to be able to spell the names of objects. The choice of letters to write the names of objects has been provided in this gameplay menu. To motivate children to play this gameplay, sammy the cat is also given animation, in the form of idle, happy and sad animation, which will be executed based on the user's answer is right or wrong, besides that, it is also given cheers of joy and animation of fireworks, if the child answer correct.

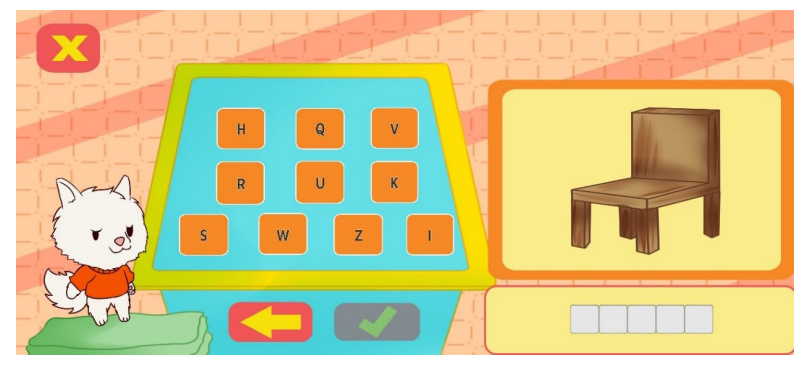

Figure 6: The third gameplay, Compositing letters gameplay

All the gameplay can be played in two languages, namely in Indonesian or English. All the gameplay are designed with the addition of cute character elements, animated characters and praise sounds, that aim to make children enjoy the educational game, and to motivate children to can play education games.

\section{RESULT}

After this education game has been made, then testing is carried out for 15 early childhood to determine the level of user acceptance and to get information, is the target or aim of adding elements of entertainment game can be achieved? Testing will be carried out using the User Acceptance Test (UAT) method. After the child is tried education game that has been made, the child will be given time to try the education game for a week, to find out whether the education game is still popular in the child or the child show signs of refusal to continue playing this education game. After a week, the children tried the education game, a questionnaire will be taken with the assistance of the child's parents, so they could answer the questions from the questionnaire given. In Figure 7 , is shown photo some children trying to play the education game that has been made.

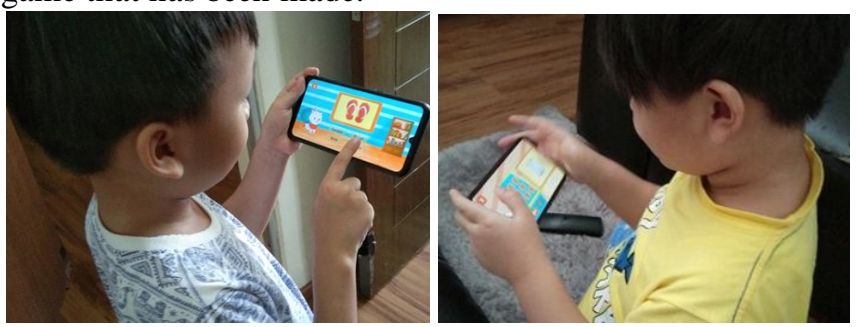

Figure 7: Some children are trying to play a game that has been made

This is list a questions of questionnaire, which asked for parents with the children who have tried playing the game for a week, the first one will be asked, "Is the child still plays the education game that was made after trying it for a week?" (P1). And the second question is, "does the child look happy or enjoy playing the education game?" (P2). The third question is, "do children like the characters, animation and design in the game?" (P3). The fourth question is, "is the learning content in the education game interesting for children?" (P4). The last question is, "is this education game helps children in recognizing objects?" (P5).

From the questions were given to respondent, they can give the answer based on optional answer that provided, where the optional answer that given are SA, A, N, D and SD. Where the answer SA which mean strongly agree, and for the A answer which mean Agree, for the $\mathrm{N}$ answer which mean Neutral, for D answer which mean Disagree and the SD answer which mean strongly disagree. Then to get the percentage, the total answer respondents is multiplied by the number of respondents, which is 15 , so the percentage results will be get, that are shown in Table 2 .

Table 2: User acceptance test percentage result

\begin{tabular}{|c|c|c|c|c|c|c|c|c|c|c|}
\hline \multirow{2}{*}{$\begin{array}{c}\text { Ques } \\
\text { tion }\end{array}$} & \multicolumn{5}{|c|}{ Grade } & \multicolumn{6}{|c|}{ Percentage } \\
\cline { 2 - 11 } & SA & A & N & D & SD & SA & A & N & D & SD \\
\hline P1 & 0 & 4 & 6 & 6 & 10 & $0 \%$ & $7 \%$ & $13 \%$ & $20 \%$ & $67 \%$ \\
\hline P2 & 0 & 8 & 9 & 8 & 6 & $0 \%$ & $13 \%$ & $20 \%$ & $27 \%$ & $40 \%$ \\
\hline P3 & 10 & 4 & 15 & 10 & 2 & $13 \%$ & $7 \%$ & $33 \%$ & $33 \%$ & $13 \%$ \\
\hline P4 & 15 & 24 & 18 & 0 & 0 & $20 \%$ & $40 \%$ & $40 \%$ & $0 \%$ & $0 \%$ \\
\hline P5 & 30 & 20 & 9 & 2 & 0 & $40 \%$ & $33 \%$ & $20 \%$ & $7 \%$ & $0 \%$ \\
\hline
\end{tabular}


From the percentage results that have been obtained in Table 2 , then to get the final grade, the number of respondents is calculated multiplied by the answer value, where SA has score 5, A has score 4, N has score 3, D has score 2, and SD has score 1 . Then from these results, it can be used to get the total and percentage value of user acceptance for each question, where from the total, it can be used to get the average value of user acceptance, which is obtained from the total number of the summary divided by the number of questions Then the average value of user acceptance of this application is $57.6 \%$ as shown in Table 3.

Table 3: User acceptance test result

\begin{tabular}{|c|c|c|c|c|c|c|c|c|}
\hline \multirow{2}{*}{ Question } & \multicolumn{5}{|c|}{ Grade } & \multirow{2}{*}{ Sum } & \multirow{2}{*}{ Anl } & \multirow{2}{*}{ Prc } \\
\hline & 5 & 4 & 3 & 2 & 1 & & & \\
\hline Q1 & 0 & 4 & 6 & 6 & 10 & 26 & 1,73 & 35 \\
\hline $\mathrm{Q} 2$ & 0 & 8 & 9 & 8 & 6 & 31 & 2,07 & 41 \\
\hline Q3 & 10 & 4 & 15 & 10 & 2 & 41 & 2,73 & 55 \\
\hline $\mathrm{Q} 4$ & 15 & 24 & 18 & 0 & 0 & 57 & 3,80 & 76 \\
\hline Q5 & 30 & 20 & 9 & 2 & 0 & 61 & 4,07 & 81 \\
\hline
\end{tabular}

For evaluation of the results of the games that have been made, questions or interviews will be asked to respondents, If the results of the scores given by the respondent in questionnaire are in grade 1 or grade 2, this is done to obtain information on the reasons or explanations from the informants. And in Table 4 is a recap of the reasons or explanations that have been given by some parents as respondents from this questionnaire.

Table 4: Recapitulation of the explanation and reasons why the respondents gave low scores

\begin{tabular}{|c|c|c|}
\hline \multirow{2}{*}{$\begin{array}{c}\text { Que } \\
\text { tion }\end{array}$} & $\mathbf{2}$ & \multicolumn{2}{|c|}{ Grade Reason } \\
\cline { 2 - 3 } Q1 & $\begin{array}{c}\text { Children only play for a } \\
\text { moment, then return to their } \\
\text { favorite games to can play } \\
\text { together with they friend. }\end{array}$ & $\begin{array}{c}\text { Children only play } \\
\text { education games for 1 to 2 } \\
\text { days, because the content is } \\
\text { not too much, making the } \\
\text { game finish quickly }\end{array}$ \\
\hline Q2 & $\begin{array}{c}\text { Children are not too } \\
\text { interested in playing these } \\
\text { education games }\end{array}$ & $\begin{array}{c}\text { Children are only interested } \\
\text { in the beginning when } \\
\text { playing the education game }\end{array}$ \\
\hline Q3 & $\begin{array}{c}\text { Children are not too } \\
\text { interested, because the } \\
\text { character animation } \\
\text { movement is only a little in } \\
\text { this game }\end{array}$ & $\begin{array}{c}\text { Children are interested but } \\
\text { not very fond, because there } \\
\text { is no control for the } \\
\text { characters }\end{array}$ \\
\hline Q4 & - & $\begin{array}{c}\text { Children are a little helped } \\
\text { in recognizing objects and } \\
\text { can know the names of } \\
\text { objects in Indonesian and } \\
\text { English, }\end{array}$ \\
\hline & - &
\end{tabular}

From the results of the questionnaire and interview, it shows that education games with the addition of several elements of entertainment games, such as character elements, praise sound, animation, and colourful user interface designs have not been able to attract early childhood to be able to continue playing this education game. This is indicated by the average result of the questionnaire only worth $57.6 \%$, which shows that there needs to be a significant increase in the education games that have been made, both in terms of character, animation, user interface design, and the content of the learning content. From the results of the interview, it can also be concluded that the child's disinterest in this game education, also is come from a gameplay, which is very different gameplay from entertainment game gameplay, and also because peers who play entertainment games, make children interested in playing with same entertainment games.

\section{CONCLUSION}

An education game with the application of several entertainment game elements, such as character elements, animations in the background and characters, voices of praise to players and an attractive colorful user interface has been successfully created. From the results of the questionnaire, it was found that children still prefer game entertainment, due to several reasons such as unattractive gameplay, non-interactive characters, and game content that is too boring, which only have quizzes contains, thus making children not really like it. Although entertainment games have been added in education games, the result children's interest rate is only $57.6 \%$. It can also be concluded that the children also prefer to play the games that are known by many people and by their friends, so they can also play together in these games. So that even though the elements of entertainment games have been applied to education games, if the presentation of the gameplay is not good, then the children will not like the game.

\section{FUTURE WORK}

Based on the conclusions and the results that have been obtained, for the development of an education game, the element character in the education game should not only be used as a mascot, but must has an important role for completing the game, such as moving, jumping and other actions. On the gameplay side, an education games should not only be in the form of quizzes or question and answer, but can also be like an entertainment games in general, such as Role Playing Game (RPG) genre, side scrolling games genre or action adventures genre that are more loved by children.

\section{ACKNOWLEDGEMENT}

This project was supported and funded by Universitas Multimedia Nusantara, Tangerang, Indonesia. Also, we would like to thank for all of the programmer and 2D artist 
who make this game project, especially for Game Laboratory Universitas Multimedia Nusantara and for all participant who contributed their time to take part in this research.

\section{REFERENCES}

1. P. Eadie, P. Levickis, L. Murray, J. Page, C. Elek, and A. Church, "Early Childhood Educators' Wellbeing During the COVID $\square 19$ Pandemic," Early Childhood Education Journal, no. April, 2021.

2. K. Kushlev and E. W. Dunn, "Smartphones distract parents from cultivating feelings of connection when spending time with their children," Journal of Social and Personal Relationships, vol. 36, no. 6, pp. 1619-1639, 2019.

3. R. Fajar Amalia and A. Yani Syuhaimie Hamid, "Adiksi Smartphone, Kesehatan Mental Anak, Dan Peranan Pola Asuh," Jurnal Ilmu Keperawatan Jiwa, vol. 3, no. 2, pp. 221-240, 2020.

4. E. J. Lee and Y. Ogbolu, "Does Parental Control Work with Smartphone Addiction?: A Cross-Sectional Study of Children in South Korea," Journal of Addictions Nursing, vol. 29, no. 2, pp. 128-138, 2018.

5. A. Gralczyk, "Smartphone and Tablet in the Everyday Life of Preschool Children. Impact and Educational Options in the Opinion of Parents and Teachers of Kindergarten.," Social Communication, vol. 5, no. 2, pp. 85-102, 2019.

6. G. Kokkalia, A. S. Drigas, and A. Economou, "Mobile learning for preschool education," International Journal of Interactive Mobile Technologies, vol. 10, no. 4, pp. 57-64, 2016.

7. A. W. Istiono and A. Waworuntu, "INTERNATIONAL JOURNAL OF ADVANCED STUDIES IN COMPUTER SCIENCE \& ENGINEERING What element that influence preschool and elementary school children to enjoy playing education games?," INTERNATIONAL JOURNAL OF ADVANCED STUDIES, vol. 9, no. 12, pp. 9-13, 2021.

8. J. Sampurna and W. Istiono, "Virtual Reality Game for Introducing Pencak Silat," International Journal of Interactive Mobile Technologies, vol. 15, no. 1, pp. 199-207, 2021.

9. R. E. Clark, "Evaluating the Learning and Motivation Effects of Serious Games," Center for creative technologies 5/9/2021, 2006.

10. R. E. Clark and S. Choi, "Five design principles for experiments on the effects of animated pedagogical agents," Journal of Educational Computing Research, vol. 32, no. 3, pp. 209-225, 2005.

11. S. Papadakis, J. Vaiopoulou, M. Kalogiannakis, and D. Stamovlasis, "Developing and exploring an evaluation tool for educational apps (E.T.E.A.) targeting kindergarten children," Sustainability (Switzerland), vol. 12, no. 10, pp. 1-10, 2020.

12. G. B. Ramani and C. A. Brownell, "Preschoolers' cooperative problem solving: Integrating play and problem solving," Journal of Early Childhood Research, vol. 12, no. 1, pp. 92-108, 2014.

13. P. Kirschner, J. Sweller, and R. Clark, "Why Unguided Learning Does Not Work: An Analysis of the Failure of Discovery Learning, Problem-Based Learning, Experiential
Learning and Inquiry-Based Learning," Educational Psychologist, vol. 41, no. 2, pp. 75-86, 2006.

14. R. T. Bigueras, M. C. A. Arispe, J. O. Torio, and D. E. Maligat, "Mobile game-based learning to enhance the reading performance of dyslexic children," International Journal of Advanced Trends in Computer Science and Engineering, vol. 9, no. 1.3 Special Issue, pp. 332-337, 2020.

15. Iswinarti and D. R. Suminar, "Improving children's problem-solving skills through javanese traditional games," Cakrawala Pendidikan, vol. 38, no. 3, pp. 578-589, 2019.

16. C. Cornoldi, B. Carretti, S. Drusi, and C. Tencati, "Improving problem solving in primary school students: The effect of a training programme focusing on metacognition and working memory," British Journal of Educational Psychology, vol. 85, no. 3, pp. 424-439, 2015.

17. É. R. Gouveia et al., "The effectiveness of a tactical games approach in the teaching of invasion games," Journal of Physical Education and Sport, vol. 19, no. July, pp. 962-970, 2019.

18. Y. Kurniawati, S. Pranoto, and J. J. Hong, "Developing Early Childhood's Character Through Javanese Traditional Game," Indonesian Journal of Early Childhood Education Studies, vol. 3, no. 1, pp. 68-72, 2014.

19. S. Junaid, “Children'S Literature in Empowering Children Character Building," Elite : English and Literature Journal, vol. 4, no. 1, pp. 109-125, 2017.

20. B. Baglama, Y. Yucesoy, and A. Yikmis, "Using animation as a means of enhancing learning of individuals with special needs," TEM Journal, vol. 7, no. 3, pp. 670-677, 2018.

21. B. Islam, A. Ahmed, K. Islam, and A. K. Shamsuddin, "Child Education Through Animation: An Experimental Study," International Journal of Computer Graphics \& Animation, vol. 4, no. 4, pp. 43-52, 2014.

22. M. Bayat, "Clarifying Issues Regarding the Use of Praise With Young Children," Topics in Early Childhood Special Education, vol. 31, no. 2, pp. 121-128, 2011.

23. J. Henderlong and M. R. Lepper, "The effects of praise on children's intrinsic motivation: A review and synthesis," Psychological Bulletin, vol. 128, no. 5, pp. 774-795, 2002.

24. A. Tapp and D. L. Lively, "Think Twice Before You Speak: Using effective praise in the early childhood and university setting," Research In Higher Education Journal, pp. 1-9.

25. C. J. Boyatzis and R. Varghese, "Associations with Colors," The Journal of Genetic Psychology: Research and Theory on Human Development, vol. 155, no. 1, pp. 77-85.

26. A. Jain, "Psychological Effects of Color on Childrens Creativity: Do Cool Colors Have Stronger Impact?," International Journal of Advanced Research, vol. 8, no. 7, pp. 673-682, 2020. 